\title{
1 HIV, AIDS and the global imaginary
}

\author{
Gerry Kearns
}

\section{HIV, AIDS and the global imaginary}

The syndrome that later received the name AIDS was first announced by a communication published in the USA by the Centres for Disease Control (CDC): 'In the period October 1980-May 1981, 5 young men, all active homosexuals, were treated for biopsy-confirmed Pneumocystis carinii pneumonia [PCP]' (CDC, 1981). Looking principally at the epidemiological discussion of AIDS within the USA, I have noted the persistent homosexualisation of the condition and examined the spatial metaphors through which this prejudice was sustained (Kearns, 2016). In this chapter, I want instead to examine how AIDS has been conceptualised as an issue of global health. I will describe the geographical imaginary of the first attempts to conceptualise AIDS as an issue of global health. I will outline some of the consequences of this global imaginary for AIDS policies, both in the USA and in South Africa.

When David Stoddart $(1986,154)$ wrote about geography as a form of scientific prediction based on observations of spatial proximity, he claimed to be describing the geographical method of exploration. Yet exploration was not really like extending a jigsaw puzzle, piece by adjacent piece, but, rather, some concept of the overall picture, a global imaginary, helped explorers interpret the new data that they produced. I use the term 'imaginary' in the sense intended by Jean-Paul Sartre when he wrote of imaginary objects that manifest in the 'synthetic acts of consciousness [where] there appear at times certain structures that we call imaging consciousness' (Sartre, 2004[1940], 7). The imaginary object helps us make sense of our perceptions and in this work of imagination there is a normative investment. Webber remarks that, for Sartre, 'the patterns of salience and significance in our surroundings that motivate our actions result partly from the ways we imagine the world could be' (Webber, 2004, xxvi). Louis Althusser made a similar point when he suggested that 'Ideology represents the imaginary relationship of individuals to their real conditions of existence' (Althusser, 1971[1970], 162). A global imaginary, then, may be an understanding of how the world is and works, and it can organise our apperception of new data about the world.

In a thrilling survey of what they call 'the myth of continents', Lewis and Wigen (1997) explicate the Eurocentrism of the continental. The global imaginary 


\section{G. Kearns}

of continents set up various oppositions between Europe and a series of others. Time and again, the discourse of continents legitimated European colonialism by presenting Africa as primitive (Mudimbé, 1988), Asia as enervated (Said, 1978) and America as degenerate (Pagden, 1982). Continental thinking is over-determined both by environmentalism and by racism: other places were understood as somehow less suitable than Europe as an ecumene for progressive civilisation (Glacken, 1967) and peoples indigenous to places outside Europe were thought to be incapable of sustained progress, even if they may once have been (Carew, 1988a, 1988b). This continental imaginary and its associated racism were central to the early epidemiological concepts of the global impact of AIDS.

\section{Mapping global AIDS}

Very soon after the first cases among and early deaths from opportunistic infections of young gay men, physicians in the USA reported cases people other than gay men. Within one month of its first report on PCP among young gay men, the CDC announced cases among heterosexual injecting drug users (Shilts, 1987,83 ) and, in January 1982, when it published a summary of the new epidemic detailing 158 cases either of PCP or of another opportunistic infection, Kaposi's Sarcoma (KS), the CDC identified 12 cases among men thought to be exclusively heterosexual (CDC, 1982a, 251). The epidemic in the USA was known to be diverse almost from its eenception, and yet the earliest attempts to make sense of the epidemic at a global scale projected the space of the USA as sustaining a homosexual epidemic (Kearns, 2016). This was not simply a broad generalisation, since separate epidemics were hypothesised and were assigned to distinct global spaces.

In one of a clutch of articles in which they announced their geographical model of AIDS, researchers from the Special Program on AIDS of the World Health Organisation (WHO), together with colleagues from Belgium, Canada, Tanzania, and from the World Bank, announced that:

The available data on reported AIDS cases and HIV-1 seroprevalence provide a reasonable description of the current global patterns of infection and severe or fatal disease due to HIV-1 infection. Three distinct epidemiologic patterns of infection and disease can be distinguished.

(Piot et al., 1988, 574)

Epidemiological reasoning is often spatial, inferring process from patterns of prevalence, tracks of transmission or clustering of cases. The WHO epidemiologists identified three groups of countries based, they argued, on the pattern of AIDS (Piot et al., 1988, 577; see Figure 1.1). Pattern I countries had an epidemic where '[h]omosexual/bisexual men and intravenous drug abusers [were] the major affected groups' (Piot et al., 1988, 576). Since the 'mid-1970s or early 1980s' AIDS had been established in the Pattern I countries of 'Western Europe, North America, some areas in South America, Australia, [and] New Zealand' 


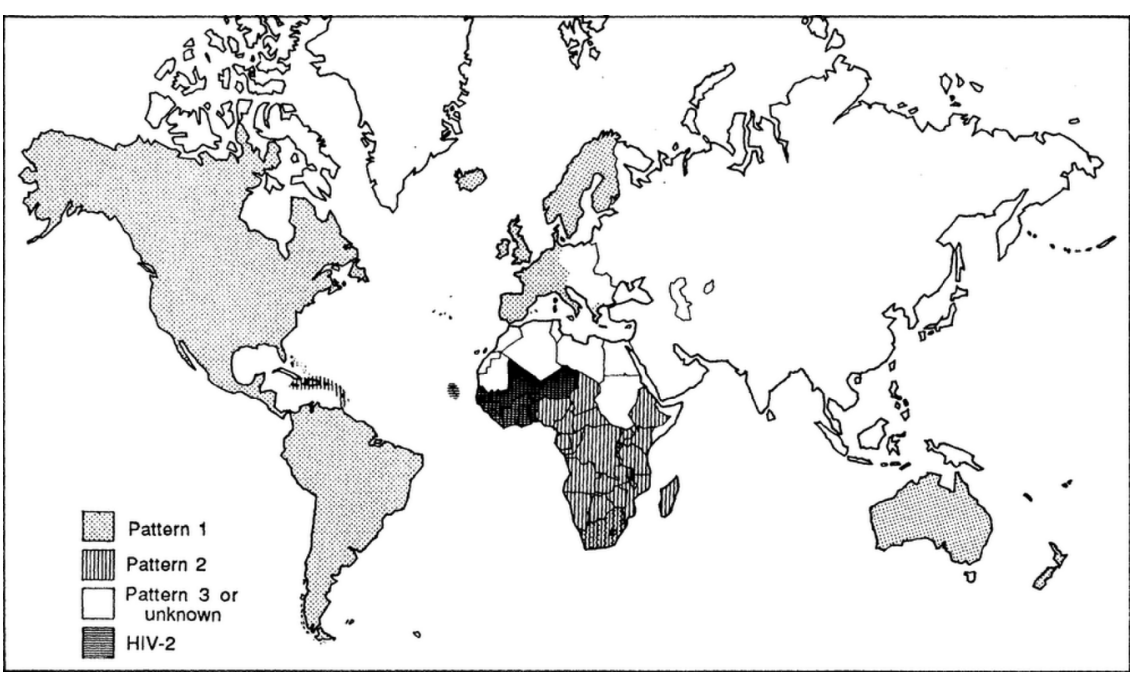

Figure 1.1 Patterns of HIV-1 infection in the world.

Source: Piot et al. (1988).

(Piot et al., 1988, 576). The Pattern 2 countries of 'Africa, Caribbean, [and] some areas in South America' had, from the '[e]arly to late 1970s', an epidemic that was '[p]redominantly heterosexual' (Piot et al., 1988, 576). In the rest of the world ('Asia, the Pacific Region (minus Australia and New Zealand), the Middle East, Eastern Europe, and some rural areas of South America'), the epidemic had started a little later, the '[e]arly to mid-1980s', and there was a '[v]ery low prevalance of HIV' (Piot et al., 1988, 576). There are a number of problems with this identification of distinct epidemics in different places, and in particular with the continental basis of the classification of epidemics.

In the first place, the data were so patchy that generalising to the level of individual continents was a heroic undertaking. The epidemiologists at the WHO knew that their data were incomplete, particularly, they believed, in the case of the countries of Africa:

Reporting of AIDS cases from Africa has in general been delayed and incomplete. The reasons for this include the limited access of large segments of the population to health care facilities where the diagnosis of AIDS can be established, the low efficiency of surveillance systems, the general lack of facilities for the diagnosis of AIDS, and the reluctance of some governments to officially acknowledge the existence of AIDS until 1987.

(Piot et al., 1988, 573-574)

A great deal of effort was expended in cajoling countries into admitting the presence of AIDS within their borders. Once a single AIDS case had been conceded, 


\section{G. Kearns}

the WHO could follow up by asking for, and recommending the form of, a national AIDS prevention and treatment strategy. As of early December 1987, the WHO had received notification of AIDS in 129 of the 161 countries submitting mortality reports. Thus, if similar countries were grouped together, the documented experience of some might serve as proxy for the profile of vulnerability unacknowledged in others. In this first decade of the epidemic, global health data served advocacy rather than planning (Ghys et al., 2006). Projecting a global pandemic engaged the attention of multilateral agencies, justifying expenditure and intervention by the WHO, and later the World Bank and other agencies of the United Nations (UN).

\section{Interpolation and exceptions}

To project a global epidemic, it would help if the map had no gaps. The maps produced by the epidemiologists were based, although with significant exceptions, on countries grouped into continents. Thus, Asia was typified as having the Type III epidemic with low prevalence and an epidemic starting in the mid-1980s. Yet, in 1988, there had been no cases at all reported from Afghanistan, Bangladesh, Bhutan, Brunei, Dar-es-Salaam, Burma, Kampuchea, North Korea, Laos, Maldives, Mongolia or Vietnam, and only three each from China, Indonesia and Sri Lanka (Panos, 1989a). The map in the Science article of 1988 is less confident than the text, indicating only that for Asia, North Africa and Eastern Europe there was 'Pattern 3 or unknown' (Piot et al., 1988, 577), but in another article of the same year, the same region is given as 'Pattern III' without qualification (Chin and Mann, 1988, s250). All of Western Europe was shown as having a Pattern 1 epidemic, with predominantly hexpexual transmission and an epidemic starting in the period from the mid-1970s to the early 1980s. Cumulative data reported for September 1989 showed that in several of the countries of Western Europe more than two-thirds of the AIDS cases reported had indeed been for people identifying as homosexual (ranging from 81 per cent in the United Kingdom down to 67 per cent in Denmark, with the Netherlands, Finland, Iceland, Sweden, Norway, West Germany and Belgium falling in descending order between the two). However, in Austria, Portugal, Ireland, Malta, Spain and Italy, this group was not the majority of the epidemic, making up only 16 per cent of the epidemic in Italy and 18 per cent in Spain (Panos, 1989b). Identifying the epidemic as primarily about sexuality (homosexual in Pattern I countries, heterosexual in Pattern II) hid the vulnerability of injecting drug users (by September 1989, 66 per cent of cumulative AIDS cases in Italy, and 62 per cent in Spain; Panos, 1989b).

In an article of 1990, Chin gave HIV infection rates by gender for each continent. It can only have been interpolation that produced for Europe and Australasia precisely the same estimated rates; one in 200 for males and one in 1400 for females (Chin, 1990, s280). It might appear at first blush that this is no more than the developmental logic that Reubi (2015) finds in the global epidemiological understanding of tobacco addiction. However, I will suggest that this interpolation was based on racialised common sense about continents. A global 
imaginary of racial continents gave the general pattern; and the racial basis of this reasoning is further indicated by the distribution of exceptions. The Americas, north, south and central, were shown as Pattern I, apart from a part of the Caribbean that included Haiti (Piot et al., 1988, 577). Paul Farmer (1992) has remarked upon Haiti's status as the first black republic in the western hemisphere (1804) and as thereby raising the ire of contemporary white slave-owning societies, most notably the USA. Its status as a sort of speck of Africa in the backyard of the USA is a measure of the persistent stigma attaching to this small country (Potter, 2009). In 1988, there were several countries in the Caribbean which had yet to report even as many as ten cases of AIDS and the only countries reporting substantial numbers of cases were Haiti and Puerto Rico; coincidentally the places with perhaps the most intense interaction with the USA (Panos, 1989a). At this time, the 5715 AIDS cases in the Caribbean (Panos, 1989a) were swamped by those of the USA (102,621 cases by August 1989; Panos, 1989b). Over its vast territory the cumulative case prevalence in the USA was 407 cases reported per million people living in 1989, compared to 298 per million in Haiti, but 574 in Puerto Rico and 1345 in the Bahamas. To single out the Caribbean epidemic while treating as a single unit the contiguous land mass of the Americas, north and south, follows a suggestive racial historical geography.

The same logic extends to the preliminary mapping of Africa. Once more there was a very broad-brush geography: North Africa as Pattern III and the rest of Africa Pattern II. But, again, there is a significant exception: South Africa. In an article of 1988 this was the only country in the world shown as having a complex epidemic, a mix of Pattern I and Pattern II. We might ask why this one place was shown as having a mixed epidemic: both a heterosexual and a homosexual epidemic. This conclusion was certainly not dictated by the data. In fact, in terms of cases reported, the AIDS epidemic in South Africa looked very like the so-called Pattern 1 countries. As of 19 April 1988: 'A total of 98 cases had been notified and broken down into risk categories . . . - the majority of cases $(81 \%)$ falling into the male homosexual/bisexual category' (Schoub et al., 1988, 153). In fact, 81 per cent was equal to the comparable figure for the United Kingdom, the European country with the highest proportion of its cases reported for men identified as homosexual.

On the face of it, it seems odd to have introduced an exception for South Africa, highlighted as the only mixed epidemic in Africa, indeed anywhere in the world. The 98 cases in South Africa from an African total of 19,141 reported by 31 October 1988 (Chinn and Mann, 1988, s249) hardly constituted a significant epidemiological exception at the time. On purely numerical grounds, it would have been more accurate to say that the USA, rather than South Africa, was a mix of Pattern 1 and Pattern 2. It is tempting to conclude that South Africa was characterised as a combination of two patterns because, like oil and water, its black and white people were understood as separate populations, and with a majority black population but a minority white government at the time the characterisation as South Africa as black and hence as likely to have a Pattern 2 epidemic was as questionable as the characterisation of the country as white and thus to be included with the other white countries as having a Pattern 1 epidemic. 


\section{African AIDS}

The racialisation of epidemiological reasoning is clear in the way that being African was constructed as itself predisposing people to contracting AIDS. An early communication in The Lancet about AIDS among people of African origin began by listing the known risk groups for AIDS, remarking that the condition had been found in 'homosexual or bisexual men, in drug addicts, in haemophiliacs, and in Haitian immigrants'; but, the authors remarked: 'To our knowledge there is no report of AIDS and opportunistic infections in previously healthy Black Africans with no history of homosexuality or drug abuse' (Clumeck et al., 1983). Absent identification as homosexual, or as injecting drug users, or haemophiliacs, then, the description of AIDS among black Africans hospitalised in Belgium 'suggests that Black Africans, immigrants or not, may be another group predisposed to AIDS' (Clumeck et al., 1983). Jan Zita Grover (1987) carefully unpicked the dangers of focusing upon risk groups rather than risk behaviours and here we can see very clearly that the risk group language stigmatised identities or, in this case, the occupants of a whole continent, or, rather, the black inhabitants of that continent.

This had consequences for the ways in which AIDS was thought about in some African countries producing, for example, a strongly racialised understanding of AIDS in South Africa. Schoub and co-workers described the AIDS cases among 79 homosexual men as 'a Western AIDS pattern occurring mainly in the white population', whereas the cases of '[seven] black patients' represented 'the beginnings of heterosexually acquired African AIDS' (Schoub et al., 1988, 153). The white men were described as Western, but the black people were African. This is the global imaginary of early AIDS epidemiology, wherein racialised continents structured understandings about the development and expectations about the future trajectory of the epidemic. This imaginary drew upon long-standing notions of darkest Africa (Jarosz, 1992) but in developing an idea of African AIDS, epidemiologists gave a new twist to the idea of Africa as a place where nature was just too strong for local culture, reinforcing a fatalistic view of Africa as naturally a development basket case (Dada, 1990; Patton, 1990). AIDS became an index of an African fatality that clung both to the land and to its black people. Much the same may be said of the association of AIDS with Haiti, in effect, 'the stigmatization of an entire nation' (Pape and Johnson, 1993, s345):

Stigma stains the imaginary and informs our understanding of Haiti.... Perhaps stigma is paired with AIDS even more frequently than the ubiquitous phrase 'the poorest country in the Western Hemisphere' is yoked to Haiti. As Elizabeth Abbott has argued, 'AIDS stamped Haiti's international image as political repression and intense poverty never had.'

(Jean-Charles, 2011, 63, quoting Abbott, 1988, 255)

Alongside the treatment of being African/black as a risk factor, much of the early epidemiology also proposed that African AIDS was different, and that African 
AIDS included the AIDS among black Haitians. One early article, reporting on Uganda, suggested that there was infection with HIV (at the time called HTLVIII and LAV) but that the clinical expression in Uganda suggested the presence of a distinctive disease:

The first patients were seen in 1982 and new ones are being seen with increasing frequency. Most patients present with fever, an itchy maculopapular rash, general malaise, prolonged diarrhoea, occasional respiratory symptoms, and oral candidiasis, but the most dominant feature is extreme wasting and weight loss. Hence the syndrome is known locally as slim disease.

(Serwadda et al., 1985, 849)

In Uganda they observed that '[s]lim disease occurs predominantly in the heterosexually promiscuous population' (Serwadda et al., 1985, 849). In the Rakai district, bordering Tanzania, HTLV-III was endemic with 10 per cent of adults tested showing seropositivity. In this region the border was crossed repeatedly by traders, and, from 1980, by Tanzanian soldiers. Of 15 traders tested, ten were positive: 'These traders admitted to both heterosexual and homosexual casual contacts. Tanzanian soldiers ... have had frequent heterosexual contact with the local population' (Serwadda et al., 1985, 852). Many of the early cases of AIDS among African people were reported by epidemiologists in Europe, particularly Belgium and France which saw African patients who had either travelled to Europe for treatment or who fell ill while in Europe, as with: 'A previously healthy, married 23-year-old black woman [who] left Zaire for Belgium in June 1981. Neither she nor her husband were drug abusers. Eight days after arriving in Belgium she was hospitalized with fever, weakness, subclavicular adenopathy, and splenomegaly' (Offenstadt et al., 1983). She died in March 1982 after clinical tests had already established the collapse of her immune system in the manner diagnostic of AIDS.

Epidemiologists who had been working on AIDS among black African men treated in Belgium noted the epidemiological and clinical distinctiveness of African AIDS: the sex ratio of patients was more even, and the opportunistic infections among cases from Africa were 'quite similar to those reported among AIDS patients in Haiti, but [were] slightly different from those in the USA' (Colebunders et al., 1985, 10). Reporting on AIDS in the tropics, one early work by Belgian epidemiologists distinguished between an epidemic spread ('un envoi épidémique'; Taelman and Piot, 1984, 331) of the disease in the USA on the one hand, and a disease that could be considered endemic in central Africa and in Haiti such that one might speak of these regions as hearths or at least focii of the disease: '[L]es médecins haïtiens identifient un foyer de SIDA en Haïti confirmant ainsi l'endémicité du SIDA dans ce pays' (ibid.). This distinction in epidemiological pattern separated the Western from the African/Haitian diseases, suggesting that the rapid spread in the first was subsequent to the earlier undetected establishment of the second. Yet, neither of the works cited on AIDS in Haiti offered such a speculation. 
One of the studies did indeed suggest that AIDS in Haiti, and among Haitians in the USA, had a distinctive clinical expression, principally 'diarrhoea, fever, weight loss, and Candida oesophagitis' (Malebranche et al., 1983, 876), but the authors made no comment on the endemicity of AIDS in Haiti and did not propose that there was a different type of AIDS in Haiti. On the contrary, they suggested that the gastro-intestinal conditions they observed were unlikely to be 'directly related to the putative causal agent of AIDS' but were probably 'related to infectious complications of the underlying immune disorder' (Malebranche et al., 1983, 877). In other words, the mix of opportunistic infections varied with context, climatic or social, but AIDS was fundamentally the same disease. The other study from Haiti cited by Taelman and Piot, rather than identifying differences between Haiti and the USA, in fact underlined the similarities both in the nature of the disease and in the moment of its appearance:

The first cases of Kaposi's sarcoma and opportunistic infections in homosexual men in the United States were documented in early 1978. We do not believe that AIDS was present in Haiti before 1978. This contention is supported by the clinical experience of the practicing pathologists and dermatologists in Haiti and by our inability to identify earlier cases through examination of autopsy and biopsy records. It also seems likely that Haitians would have presented to U.S. hospitals sooner if AIDS had been occurring in Haiti before 1978 .

(Pape et al., 1983, 949)

In drawing a distinction between epidemic AIDS in the USA and endemic AIDS in Haiti, or in Africa, the epidemiologists were over-reaching the evidence. There was a similar bias towards distinguishing African/Haitian AIDS from US AIDS even in the discussion of the sickness among Haitian immigrants inside the USA. The first report from the CDC covered 34 cases, of which 30 were male, and in this respect very like the majority of cases in the USA at that time. However, the CDC reported that ' $[n]$ one of the 23 Haitian males questioned reported homosexual activity, and only one gave a history of IV drug abuse' (CDC, 1982b, 360). Rather than questioning the reliability of this testimony, the CDC made Haitians a distinct risk group alongside homosexuals, intravenous drug users and haemophiliacs. This construction of Haitian/African AIDS had serious consequences, and not only for Haiti where the collapse of tourism was immediate: '[T]he Haitian Bureau of Tourism estimated that tourism declined from 75,000 visitors in the winter of $1981-82$ to under 10,000 the following year' (Farmer, 1992, 146).

\section{Postcolonial AIDS}

The epidemiological construction of a distinctively African AIDS was readily identified as racist by many cultural critics (Austin, 1990; Bass, 1998; Dada, 1990; O’Malley, 1992; Patton, 1990; Treichler, 1989; Watney, 1989). A Canadian 
journalist, Renée Sabatier (1988), covering the epidemic from a third-world perspective, identified both the risks of the AIDS epidemic for developing countries and also documented the racism and prejudice that informed many AIDS policies. In 2001, contemplating the provision of expensive combination antiretroviral (ARV) therapy in Africa, the head of the United States Agency for International Development was in despair. Africans, he said, 'don't know what watches and clocks are', and thus could not be expected to stick to a treatment regime that required time discipline in the ingesting of medicines (Attaran, 2007). AIDS was fated for Africa, both natural and untreatable. In fact, when effective therapies were provided, compliance among African people was found to be better than in North America itself (Attaran, 2007).

My argument thus far has been that the geographical imaginary that shaped perceptions and representations of AIDS in epidemiology found it too easy to organise the world around racialised continents. I have suggested that there was a policy intention behind interpolation, with data being stretched to allow the concept of a global epidemic, presenting AIDS as a crisis to which every state must needs respond. I have also claimed that the treatment of certain spaces as exceptions to the continental geography of AIDS underlined the essentially racial basis of this geography. I have further proposed that in distinguishing African from Western AIDS, epidemiologists often went further than the data dictated and certainly drew inferences that were resisted by some scientists from the countries that were designated as Pattern II, the African AIDS.

Alongside the racialised categories of some global epidemiological models, there was certainly also explicitly racist commentary in other quarters. The scientific work was sometimes the occasion or excuse for sensationalist and offensive commentary in the mass media (Lupton, 1994). The link between science and tabloid journalism was a commonsense global imaginary of the West. It has two main parts. The first is that epidemic disease is naturally localised in certain deviant groups who are thereby a risk to the 'general population' (Grover, 1987). The second is that epidemic disease comes from outside the West. Of course, this builds on a long history from the Asiatic cholera of the 1830s (Morris, 1976) to the Asiatic flu of 1889 to 1890, 'the first named flu pandemic' (Ryan, $2008,16)$. In both respects, Western common sense is animated by disgust in precisely the way Nussbaum $(2004,14)$ indicates: 'its thought-content is typically unreasonable, embodying magical ideas of contamination, and impossible aspirations to purity, immortality, and nonanimality.' The black body was implicated both socially and spatially in this geopolitics of disgust, as the diseased 'other' both inside and outside the West.

This directly and indirectly endangered black lives. With the disease incorporated into the general white disgust at black bodies, it became very difficult for people of colour to acknowledge their own vulnerability. Respectable black opinion distanced itself from the sorts of bodies stigmatised by racist commentary, bodies that injected drugs or had sexual relations outside heterosexual marriage (Cohen, 1999). Needle-exchange schemes were represented as attempts to promote drug use among African-Americans and on those grounds rejected, as 


\section{G. Kearns}

when New York City's first African-American mayor closed down one such programme (Anderson, 1991). In a study of sex education and HIV prevention in the USA, Patton (1996) noted that the representation of African-American males as deviant, as early and hyper-sexualised, produced defeatism, invalidating programmes that may otherwise have addressed their needs. In broad terms, African-Americans were ill-served by what Geary $(2014,18)$ describes as 'the discourse of queers'; that is, by their treatment as deviants.

Similar difficulties attended the reception of African AIDS discourse in the African countries themselves. In reaction to the stigmatising of Africa as the source of AIDS, and in the mid-1980s, the introduction by Western countries of testing for students and other visitors from certain African countries, commentators in Africa challenged the Western science and the Western policies. At a time when there were more AIDS cases reported from many Western than from African countries, Ochieng (1987), for example, suggested that if the West were truly concerned to limit the spread of the disease it would screen its own residents before allowing them to travel abroad, rather than imposing restrictions upon visitors from Africa. In a comprehensive review of all the grounds for scepticism, Chirimuuta and Chirimuuta $(1987,3)$ asked: 'How is it possible that this predominantly American disease has been attributed to the African continent?' Their reply was unequivocal: '[T]he medical "experts", the media and the public at large are affected by the insidious and unrecognised disease of racism' (p. 136).

There was justified scepticism about claims that AIDS was widespread and of long standing in Africa, and that AIDS in Africa and among people of African descent was very different from Western AIDS. There was also justified anger that, in concluding so quickly that AIDS was best understood as an African disease, Western scientists and commentators were repeating the stereotypes current during the colonial era; that Africa was naturally disease-ridden, and that only Western technology could mitigate the impress of an unfavourable African disease-ecology. However, in reacting against the colonialist construction of diseased Africa, African politicians and scientists ran the risk of viewing AIDS only as a Western projection lacking any other substance. As more African people became infected with the HIV virus, and later died from the opportunistic infections, denying the reality of AIDS became ever more dangerous, reaching its apogee in the arguments of Thabo Mbeki when, as president of South Africa, he took direct control of his country's anti-HIV programmes. This new discourse on AIDS was an alternative global imaginary and, in retaining as an explicit rejection the earlier colonialist discourses on diseased Africa, it deserves to be called postcolonial.

Mbeki's postcolonial concept of AIDS challenged the Type I/Type II global imaginary. Mbeki repudiated what he called the 'African exceptionalism' that presented African people as 'a peculiar species of humanity' (Mbeki, 1998a). This exceptionalism, he argued, was colonialist:

To perpetuate their imperial domination over the peoples of Africa, the colonisers sought to enslave the African mind and to destroy the African soul. 
They sought to oblige us to accept that as Africans we had contributed nothing to human civilization; except as beasts of burden. . . . In the end, they wanted us to despise ourselves, convinced that, if we were not sub-human, we were, at least, not equal to the colonial master and mistress.

(Mbeki, 1998b)

To repudiate the neo-colonial hold of such ideologies, African peoples must, he suggested, cultivate a profound autonomy:

[S]trengthening the genuine independence of African countries and continent in their relations with the major powers and enhancing their role in the determination of the global system of governance in all fields, including politics, the economy, security, information and intellectual property, the environment and science and technology.

(Mbeki, 1999)

Autonomy would redress 'the perception that as a continent we are condemned forever to depend on the merciful charity which those who are kind are ready to put into our begging bowls', and, in 'a genuine liberation', would put 'an end to the tragic sight of the emaciated child who dies because of hunger or is ravaged by curable diseases because their malnourished bodies do not have the strength to resist any illness' (Mbeki, 1998a). As Gevisser (2007) has shown, this vision of an African renaissance informed most aspects of Mbeki's presidency (19992008), including its AIDS policies.

When the International AIDS Conference came to Durban in 2000, Mbeki, as president of South Africa, welcomed its delegates in a speech that reached back, beyond the introduction of successful anti-retroviral therapies in 1996, to the arguments of the WHO in 1995, and quoted the opening of the report:

The world's most ruthless killer and the greatest cause of suffering on earth is listed in the latest edition of WHO's International Classification of Diseases, an $\mathrm{A}$ to $\mathrm{Z}$ of all ailments known to medical science, under the code Z59.5. It stands for extreme poverty.

(WHO, 1995, 1)

This code is part of Chapter 21 of the International Statistical Classification of Diseases and Related Health Problems (10th revision). This section concerns 'Factors influencing health status and contact with health services', and supplements but does not replace the classification of diseases. The WHO classification identifies the 'underlying cause of death', the 'precipitating cause' that is preventable:

The most effective public health objective is to prevent the precipitating cause from operating. For this purpose the underlying cause has been defined as '(a) the disease or injury which initiated the morbid events leading directly 
to death, or (b) the circumstances of the accident or violence which produced the fatal injury.'

(WHO, 2004, 23)

The WHO specifically counsels that the codes in Chapter 21 should 'not be used ... for primary mortality coding' and that they are to be understood as recording 'some circumstance or problem ... which is not in itself a current illness or injury' (WHO, 2008, 1091). Metaphorically, one might see poverty as a cause of death and, in the wake of the bacteriological revolution, epidemiologists continued to speak of the 'predisposing causes' of sickness, with the disease organism conceptualised as the seed and the weak body or insalubrious environment understood to be its receptive soil (Warboys, 2000, 206). However, Mbeki presented HIV disease (B20-B24 in the ICD classification) and Extreme Poverty as alternative causes of death and in contemplating 'the collapse of immune systems among millions of [African] people' he concluded that with a crisis of this magnitude, 'we could not blame everything on a single virus' (Mbeki, 2001[2000], 29).

In this, of course, Mbeki was drawing upon a scepticism about Western medicine stemming in part from the work of Ivan Illich (1974). It was also reinforced by a New Public Health movement that emphasised the social determinants of health and the necessity for preventive rather than curative approaches to sickness (Ashton and Seymour, 1988). This culminated in the WHO's adoption of a positive conception of health with its Ottawa Charter for Health Promotion in 1986 where health was described as not only the absence of disease but as a state of 'complete physical, mental and social well-being' (WHO, 2009, 1). Mbeki held to an extreme version of this perspective, seeing Western medicine as both iatrogenic and as a conspiracy to defraud non-Western countries.

Against the Western medicine AZT (Azidothymidine), Mbeki, even before becoming president, had championed an African drug (Virodene), engineering the removal of the people at the Medicines Control Council who considered the African drug inefficacious (Myburgh, 2009). In this respect, Mbeki drew upon the views of what Youde (2007) calls a 'counter-epistemic community', a group of scientists intensely sceptical of viral explanations of AIDS and suspicious of the motives of other scientists promoting expensive treatments (AZT) for a condition that they had themselves defined (HIV disease). Together with others, including Peter Mokaba, a close adviser who subsequently died of AIDS, he wrote a long and rambling report on AIDS for the national executive committee of the African National Congress (Kenyon, 2008). After reviewing the history of colonial public health policies, and the racist epidemiological writings identified by Chirimuuta and Chirimuuta, the 'dissertation' (Anon., 2002, 102) argued that HIV was only one of the threats to African immune systems; poverty and nutrition were more important. Furthermore, it asserted that 'anti-retroviral drugs can neither cure AIDS nor destroy the HI virus' (Anon., 2002, 7).

Acting on this belief, Mbeki pressured his minister of health, Manto TshabalalaMsimang, to promote African treatments, including garlic, beetroot and lemon juice, for boosting immune systems (Sidley, 2000). His administration also advoc- 
ated the trial of African pharmaceuticals rather than ARVs. As Nicoli Nattrass (2012) has argued, there were serious consequences to all this. In the first place, at a time when AZT was making inroads into mother-to-child in utero transmission, South African mothers were denied this medication. Nattrass estimated that 300,000 lives could have been saved if such a prophylactic measure had been instituted. The international pressure on Mbeki was formidable. Ironically, this very proud African was seen by colleagues as having brought shame upon Africa, and, moreover, as denying South Africa access to discounted drugs. In December 2007, he was replaced as head of the ANC by Jacob Zuma whom in 2005 he had dismissed from the post of deputy president following a corruption scandal over arms sales. In September 2008 Zuma got the earlier conviction overturned and a court decided that Mbeki had brought the case against Zuma on petty political grounds (Shange, 2016). The National Executive Committee of the ANC censured Mbeki who immediately resigned as president (Lindow, 2008). Mbeki's postcolonial reading of AIDS was directly responsible for his losing both status and office.

\section{A new global imaginary}

With time, the first global imaginary of Type I/Type II countries was modified. Soon after the first maps (see Figure 1.1), the mixture of types was broadened out from South Africa, and in 1989 it was suggested that 'Latin America is in evolution from Pattern I to Pattern II epidemiology and is now classified separately as Pattern I/II' (Sato et al., 1989, s304). By 1992, many questioned the utility of including Asia, Eastern Europe, North Africa and the Middle East as a Type III pattern, characterised only by late onset. Jonathan Mann and co-workers concluded in 1992 that: 'As useful as the patterns were for developing initial understanding of differentiation within the global epidemic, the WHO nomenclature of 1987 rapidly grew out of date and needed replacement' (Mann et al., 1992, 17).

Not only this increasing complexity but also a different conception of disease ecology provoked a new global imaginary. The new conceptualisation of AIDS owed most to Mann's own work. In 1984, Mann was appointed by the CDC to lead a research team investigating heterosexual AIDS in Zaire. The team he joined was emphasising the "different and important pattern [in central Africa] compared with that of AIDS in other areas' (Piot et al., 1984, 68) and Mann was a co-author of the article in Science from which Figure 1.1 was taken (Piot et al., 1988). In 1986, Mann went to the WHO and set up the WHO's Global Programme for AIDS. In his 1987 briefing on AIDS to the UN General Assembly, Mann distinguished three epidemics. The first was of the HIV virus and this would be followed after some years by cases of AIDS as the immune systems of the HIVinfected persons declined to the point where opportunistic infections would manifest. Alongside the epidemics of HIV and later of AIDS, Mann identified a 'third epidemic, of social, cultural, economic and political reaction to AIDS, [which] is also worldwide and is as central to the global AIDS challenge as the disease itself' (Mann, 1987, 1). This third epidemic would be intensified by '[f]ear and ignorance' (p. 3). 
Mann was developing some of the ideas of the New Public Health that Mbeki had also been inspired by. In stressing the social and political determinants of health, Mann was also drawing upon the success of the capabilities approach as a new paradigm in global development thinking (Nussbaum, 2011). Mann interpreted the idea that human rights were essential to human flourishing as also suggesting that human rights were vital for the-organic integrity and longevity. This suggested, he argued, that female education was as vital to health as others find it essential to economic growth (Klasen, 2002). His new geography highlighted the global differences in the Human Development Index (Wahlberg, 2007) and related these to contrasting trajectories in the HIV/AIDS pandemic.

In this context, Mann elaborated a broad vision of the relations between health and human rights, suggesting that the promotion of human rights advanced health and that abridging those rights endangered health (Mann et al., 1994). This human rights agenda structured the new global imaginary of Geographic Areas of Affinity (GAA) that Mann developed as an alternative to the Type I/Type II patterns for describing the global pandemic (Mann et al., 1992). Countering HIV infection by promoting good education, by limiting AIDS sicknesses, by removing the stigma that prevented people from seeking treatment, and by countering social fragmentation, by including HIV-positive people as full and equal members of society, effective human rights should be, argued Mann, at the heart of national and global AIDS policies. For this reason, the GAA were defined not only on the basis of epidemiology but also as incorporating societal factors such as the Human Development Index, the Human Freedom Index, an indicator of gender equality, and a measure of the underlying rate of urbanisation. This new global imaginary was not fully accepted at the WHO, and in particular by Director General Hiroshi Nakajima. Frustrated by a leadership that conceded too much to AIDS policies setting collective protection against individual rights, Mann resigned in 1990 (Hilts, 1990).

This is an alternative global imaginary to the racialised conception of the Type I/Type II, and while it shares some features with Mbeki's postcolonial inversion of racialised geographies, it articulates something quite different. It does not treat colonialism and its legacies as a central feature of the epidemic. It asserts an inverse correlation between female empowerment and HIV vulnerability which is troubled by the evidence that intense repression of extramarital sexuality in some Islamic theocracies, or coercive imprisonment of gay men in Cuba, do indeed reduce some forms of risky behaviour, but with consequences for civil liberties that should be contested on their own terms. In other words, Mann's epidemiological imaginary is also ideological and empirically vulnerable but the full elaboration of those dimensions will require a further and longer paper.

The political salience of global disease imaginaries could not be more clear than in the fates of Thabo Mbeki and of Jonathan Mann. How we understand disease shapes how we configure global geopolitics, and, just as clearly, how we understand global interdependence affects the way we imagine our vulnerability to disease. Mbeki responded in a postcolonial register to the racialised readings in early AIDS epidemiology, and Mann responded in a liberal manner to the burden 
of disease stigma likewise created by those racialised readings. Medical Geography is always also Geopolitics.

\section{References}

Abbott, E., 1988. Haiti: The Duvaliers and Their Legacy. New York: McGraw Hill.

Althusser, L., 1971[1970]. 'Ideology and ideological state apparatuses', trans. B. Brewster, in L. Althusser, Lenin and Philosophy and Other Essays. New York: Monthly Review Press, pp. 127-186.

Anderson, W., 1991. 'The New York needle trial: The politics of public health in the Age of AIDS.' American Journal of Public Health 81(11): 1506-1517.

Anon., 2002. 'Castro Hlongwane, Caravans, Cats, Geese, Foot and Mouth and Statistics: HIV/Aids and the Struggle for the Humanisation of the African.'

Ashton, J. and Seymour, H., 1988. The New Public Health: The Liverpool Experience. Milton Keynes: Open University Press.

Attaran, A., 2007. 'Adherence to HAART: Africans take medicines more faithfully than North Americans.' PLoS Med. 4(2): e83; doi: 10.1371/journal.pmed.0040083.

Austin, S.B., 1990. 'Aids and Africa: United States media and racist fantasy.' Cultural Critique 14: 129-141.

Bass, J.D., 1998. 'Hearts of darkness and hot zones: The ideologeme of imperial contagion in recent accounts of viral outbreaks.' Quarterly Journal of Speech 84(4): 430-337.

Carew, J., 1988a. 'Columbus and the origins of racism in the Americas: Part one.' Race and Class 29(4): 1-19.

Carew, J., 1988b. 'Columbus and the origins of racism in the Americas: Part two.' Race and Class 30(1): 33-57.

CDC [Gottlieb, M.S. et al.], 1981. 'Pneumocystis Pneumonia - Los Angeles.' Morbidity and Mortality Weekly Report 30(21) (5 June): 250-252.

CDC [Curran, J.W. et al.], 1982a. 'Task Force on Kaposi's Sarcoma and Opportunistic Infections: Epidemiologic aspects of the current outbreak of Kaposi's sarcoma and opportunistic infections.' New England Journal of Medicine 306(4) (28 January): $248-252$.

CDC, 1982b. 'Opportunistic infections and Kaposi's sarcoma among Haitians in the United States.' Morbidity and Mortality Weekly Report 31(26) (9 July): 353-354, 360-361.

Chin, J., 1990. 'Global estimates of AIDS cases and HIV infections' AIDS 4(suppl. 1): S277-S283.

Chin, J. and Mann, J.M., 1988. 'The global patterns and prevalence of AIDS and HIV infection.' AIDS 2(suppl. 1): s247-s252.

Chirimuuta, R.C. and Chirimuuta, R., 1987. AIDS, Africa and Racism. Burton-on-Trent: Chirimuuta.

Clumeck, N., Mascart-Lemone, F., de Maubeuge, J., Brenez, D. and Marcelis, L., 1983. 'Acquired immune deficiency syndrome in black Africans.' Lancet 321(8325) (19 March): 642.

Cohen, C.J., 1999. The Boundaries of Blackness: AIDS and the Breakdown of Black Politics. Chicago, IL: University of Chicago Press,

Colebunders, R., Taelman, H. and Piot, P., 1985. 'Acquired immunodeficiency syndrome (AIDS) in Africa: A review.' Tropical Doctor 15: 9-12.

Dada, M., 1990. 'Race and the AIDS agenda', in T. Boffin and S. Gupta (eds), Ecstatic Antibodies: Resisting the AIDS Mythology. London: Rivers Oram Press, pp. 85-95. 
Farmer, P.E., 1992. AIDS and Accusation: Haiti and the Geography of Blame. Berkeley, CA: University of California Press.

Geary, A.M., 2014. Antiblack Racism and the AIDS Epidemic. New York: Palgrave Macmillan.

Gevisser, M., 2007. Thabo Mbeki: The Dream Deferred. Johannesburg: Jonathan Ball.

Ghys, P.D., Walker, N. and Garnett, G.P., 2006. 'Improving analysis of the size and dynamics of AIDS epidemics.' Sexually Transmitted Infections 82(Supplement 3): 1-2.

Glacken, C.J., 1967. Traces on the Rhodian Shore: Nature and Culture in Western Thought from Ancient Times to the End of the Eighteenth Century. Berkeley, CA: University of California Press.

Grover, J.Z., 1987. 'AIDS: Keywords.' October 43: 17-30.

Hilts, P.J., 1990. 'Leader in U.N.'s battle on AIDS resigns in dispute over strategy.' New York Times, 17 March; Available at http://www.nytimes.com/1990/03/17/us/leader-inun-s-battle-on-aids-resigns-in-dispute-over-strategy.html (accessed 12 March 2016).

Illich, I., 1974. Medical Nemesis: The Expropriation of Health. Edinburgh: Edinburgh University Press.

Jarosz, L., 1992. 'Constructing the Dark Continent: Metaphor as geographic representation of Africa.' Geografiska Annaler 74B: 105-115.

Jean-Charles, R.M., 2011. 'The sway of stigma: The politics and poetics of AIDS representation in "Le president a-t-il SIDA" and "Spirit of Haiti".' Small Axe 15(3): $62-79$.

Kearns, G., 2016. 'Queering epidemiology', in G. Brown and K. Brown (eds), Ashgate Companion to Geographies of Sex and Sexualities. Burlington, VT: Ashgate, pp. 263-273.

Kenyon, C., 2008. 'Cognitive dissonance as an explanation of the genesis, evolution and persistence of Thabo Mbeki's HIV denialism.' African Journal of AIDS Research 7(1): $29-35$.

Klasen, S., 2002. 'Low schooling for girls, slower growth for all? Cross-country evidence on the effect of gender inequality in education on economic development.' World Bank Economic Review 16(3): 345-373.

Lewis, M.W. and Wigen, K.E., 1997. The Myth of Continents: A Critique of Metageography. Berkeley: University of California Press.

Lindow, M., 2008. 'Why South Africa's Mbeki resigned.' Time, 20 September; available at http://content.time.com/time/world/article/0,8599,1843112,00.html (accessed 12 March 2016).

Lupton, D., 1994. Moral Threats and Dangerous Desires: AIDS in the News Media. London: Routledge.

Malebranche, R., Guérin, J.M., Laroche, A.C., Elie, R., Spira, T., Drotman, P., Arnoux, E., Pierre, G.D., Péan-Guichard, C., Morisset, P.H., Mandeville, R., Seemayer, T. and Dupuy, J-M., 1983. 'Acquired Immunodeficiency Syndrome with severe gastrointestinal manifestations in Haiti.' Lancet 322(8355) (15 October): 873-878.

Mann, J.M., 1987. 'Statement at an informal briefing on AIDS to the 42nd session of the United Nations General Assembly on Tuesday 2th October 1987.' WHO/SPA>/ $I N F / 87.12$; available at http://apps.who.int/iris/bitstream/10665/61546/1/WHO_SPA INF_87.12.pdf (accessed 12 March 1987).

Mann, J.M., Tarantola, D.J.M. and Netter, T.W., 1992. AIDS in the World. Cambridge, MA: Harvard University Press.

Mann, J.M., Gostin, L., Gruskin, S., Brennan, T., Lazzarini, Z. and Fineberg, H.V., 1994. 'Health and human rights.' Health and Human Rights 1(1): 6-23. 
Mbeki, T., 1998a. The African Renaissance, South Africa and the World. Tokyo: United Nations University; available at http://archive.unu.edu/unupress/mbeki.html (accessed 12 March 2016).

Mbeki, T., 1998b. The African Renaissance. Pretoria: Department of International Relations and Cooperation; available at http://www.dfa.gov.za/docs/speeches/1998/ mbek0813.htm (accessed 12 March 2016).

Mbeki, T., 2002[1999]. Speech by the President of South Africa, Thabo Mbeki, at the launch of the African Renaissance Institute, Pretoria, 11 October 1999. Durban: African Union Summit; available at http://www.au2002.gov.za/docs/speeches/mbeki991011. htm (accessed 12 March 2016).

Mbeki, T., 2001[2000]. 'Speech by the President of South Africa, Thabo Mbeki, at the opening session of the 13th International AIDS Conference: Durban, 9 July 2000.' Jornal brasileiro de Doenças Sexualmente Transmissíveis 13(1): 17-19.

Morris, R.J., 1976. Cholera 1832: The Social Response to an Epidemic. London: Croom Helm.

Mudimbé, V.Y., 1988. The Invention of Africa: Gnosis, Philosophy, and the Order of Knowledge. London: James Currey.

Myburgh, J., 2009. 'In the beginning there was Virodene', in K. Cullinan and A. Thom (eds), The Virus, Vitamins and Vegetables: The South African HIV/AIDS Mystery. Auckland Park, South Africa: Jacana, pp. 1-15.

Nattrass, N., 2012. The AIDS Conspiracy: Science Fights Back. New York: Columbia University Press.

Nussbaum, M.C., 2004. Hiding from Humanity: Disgust, Shame and the Law. Princeton, NJ: Princeton University Press.

Nussbaum, M.C., 2011. Creating Capabilities: The Human Development Approach. Cambridge, MA: Belknap Press.

Ochieng, P., 1987. 'Africa not to blame for AIDS.' New African 232: 25.

Offenstadt, G., Pinta, P., Hericord, P., Jagueux, M., Jean, F., Amstutz, P., Valade, S. and Lesavre, P., 1983. 'Multiple opportunistic infection due to AIDS in a previously healthy black woman from Zaire.' New England Journal of Medicine 308(13): 775.

O'Malley, J., 1992. 'The representation of AIDS in Third World development', in J. Miller (ed.), Fluid Exchanges: Artists and Critics in the AIDS Crisis. Toronto: University of Toronto Press, pp. 169-176.

Pagden, A., 1982. The Fall of Natural Man: The American Indian and the Origins of Comparative Ethnology. Cambridge: Cambridge University Press.

Panos, 1989a. 'Datafile.' WorldAIDS 3 (May): 15-20.

Panos, 1989b. 'Datafile.' WorldAIDS 6 (November): 6-8.

Pape, J.W. and Johnson Jr., W.D., 1993. 'AIDS in Haiti, 1982-1992.' Clinical Infectious Diseases 17(Supplement 2): s341-s345.

Pape, J.W., Liataud, B., Thomas, F., Mathurin, J-R., St Amand, M-M.A., Boncy, M., Pean, V., Pamphile, M., Laroche, A.C. and Johnson, W.D., 1983. 'Characteristics of the Acquired Immunodeficiency Syndrome (AIDS) in Haiti.' New England Journal of Medicine 309(16): 945-950.

Patton, C., 1990. 'Inventing "Africa AIDS", in C. Patton, Inventing AIDS. London: Routledge, pp. 77-97.

Patton, C., 1996. Fatal Advice: How Safe-Sex Education Went Wrong. Durham, NC: Duke University Press.

Piot, P., Plummer, F.A., Mhalu, F.S., Lamboray, J-L., Chin, J. and Mann, J.M., 1988. 'AIDS: An international perspective.' Science NS 239(4840) (5 February): 573-579. 
Piot, P., Taelman, H., Minlangu, K.B., Mbendi, N., Ndangi, K., Kalambayi, K., Bridts, C., Quinn, T.C., Feinsod, F.M., Wobin, O., Mazebo, P., Stevens, W., Mitchell, S. and McCormick, J.B., 1984. 'Acquired Immunodeficiency Syndrome in a heterosexual population in Zaire.' Lancet 324(8394) (14 July): 65-69.

Potter, A.E., 2009. 'Voodoo, zombies, and mermaids: U.S. newspaper coverage of Haiti.' Geographical Review 99(2): 208-230.

Reubi, D., 2015. 'Modernisation, smoking and chronic disease: Of temporality and spatiality in global health.' Health \& Place; doi: 10.1016/j.healthplace.2015.04.004.

Ryan, J.R., 2008. 'Past pandemics and their outcome', in J.R. Ryan (ed.), Pandemic Influenza: Emergency Planning and Community Preparedness. Boca Raton, FL: CRC Press, pp. 1-22.

Sabatier, R., 1988. Blaming Others: Prejudice, Race and Worldwide AIDS. London: Panos.

Said, E.W., 1978. Orientalism. New York: Vintage Books.

Sartre, J-P., 2004 [1940]. The Imaginary: A Phenomenological Psychology of the Imagination, trans. J. Webber. London: Routledge.

Sato, P., Chin, J. and Mann, J.M., 1989. 'Review of AIDS and HIV infection: Global epidemiology and statistics.' AIDS 3(suppl. 1): s301-s307.

Schoub, B.D., Smith, A.N., Lyons, S.F., Johnson, S., Martin, D.J., McGillivray, G., Padayachee, G.N., Naidoo, S., Fisher, E.L. and Hurwitz, H.S., 1988. 'Epidemiological considerations of the present status and future growth of the acquired immunodeficiency syndrome epidemic in South Africa.' SAMJ. South African Medical Journal 74(20 August): $153-157$.

Serwadda, D., Sewankambo, N.K., Carswell, J.W., Bayley, A.C., Tedder, R.S., Weiss, R.A., Mugerwa, R.D., Lwegaba, A., Kirya, G.B., Downing, R.G., Clayden, S.A. and Dalgleish, A.G., 1985. 'Slim disease: A new disease in Uganda and its association with HTLV-III infection.' Lancet 326(8460) (19 October): 849-852.

Shange, N., 2016. 'Mbeki said Zuma would be taken care of should he resign - lawyer.' News24, 17 January; available at http://www.news24.com/SouthAfrica/News/mbekisaid-zuma-would-be-taken-care-of-should-he-resign-lawyer-20160117 (accessed 12 March 2016).

Shilts, R., 1987. And the Band Played On: Politics, People and the AIDS Epidemic. New York: St Martin's Press.

Sidley, P., 2000. 'Clouding the AIDS issue.' British Medical Journal 320(7240): 1016-1016. 3. 1986. On Geography and its History. Oxford: Blackwell.

Taelman, H. and Piot, P. 1984. 'Le SIDA en région tropicale: Les foyers haïtien et africain.' Annales de la Société Belge de Médecine Tropicale 64: 331-334.

Treichler, P., 1989. 'AIDS and HIV infection in the Third World: A First-World chronicle', in B. Kruger and P. Mariani (eds), Remaking History. Seattle, WA: Bay Press, pp. 31-86.

Wahlberg, A., 2007. 'Measuring progress: Calculating the life of nations.' Distinktion: Journal of Social Theory 8(1): 65-82.

Warboys, S., 2000. Spreading Germs: Disease Theories and Medical Practice in Britain, 1865-1900. Cambridge: Cambridge University Press.

Watney, S., 1994[1989]. 'Missionary positions: AIDS, "Africa” and race', in S. Watney, Practices of Freedom: Selected Writings on HIV/AIDS. London: Rivers Oram Press, pp. 109-127.

Webber, J., 2004. 'Philosophical introduction', in J-P. Sartre, The Imaginary: A Phenomenological Psychology of the Imagination, trans J. Webber. London: Routledge, pp. xiii-xxvi. 
HIV, AIDS and global imaginary 21

WHO [World Health Organization], 1995. The World Health Report 1995: Bridging the Gaps. Geneva: World Health Organization.

WHO, 2004. ICD-10. International Statistical Classification of Diseases and Related Health Problems (10th revision), Volume 2, 2nd edn. Geneva: World Health Organization.

WHO, 2008. ICD-10. International Statistical Classification of Diseases and Related Health Problems (10th revision), Volume 1, 2008 edn. Geneva: World Health Organization.

WHO, 2009. Milestones in Health Promotion: Statements from Global Conferences. Geneva: World Health Organization.

Youde, J.R., 2007. AIDS, South Africa and the Politics of Knowledge. Burlington, VT: Ashgate.

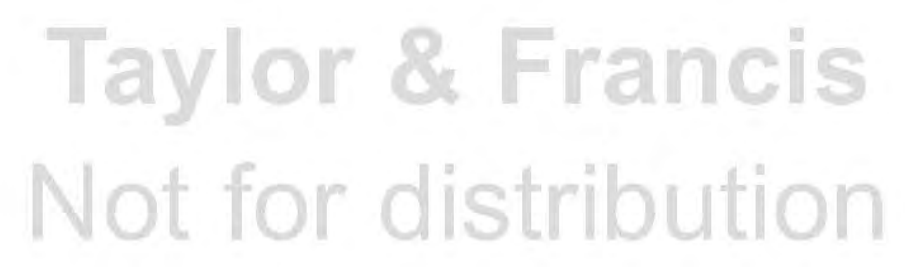

